\title{
8
}

\section{SPORT TOURISM FINDING ITS PLACE?}

\author{
Sean Gammon
}

\section{Introduction}

Watching the recent team performances that took place in the opening matches at the football world cup in Brazil, viewers could be forgiven for acquiring more enjoyment from the surprised look on the managers' faces - as they did from the open and attacking styles displayed by their teams. Why was it that even the most defensively minded of teams played more creative and expansive football? Part of the answer undoubtedly has to do with place. The ambience and atmosphere, coupled with the history and heritage of Brazilian football seemed to impact on the players (arguably in a negative way for the local team). This, albeit, over simplistic example, illustrates well the invisible connections that influence how sport tourists (in all their guises) feel, perform and behave in designated areas primarily designed for sport.

Sport tourism and place are not newly acquainted concepts in the literature. This is unsurprising given that notions of place, and its applications, lie at the heart of both the study of tourism and sport. Place reveals much about the essence and nature of sport tourism; not just from the obvious topographical perspectives but, more critically, in the manner in which it is 
experienced and embraced. Its importance cannot be underestimated, and although the fundamentals of place's influence upon sport tourism has already been established (Higham and Hinch, 2009), there is still much to explore. Yet there is a further connection that both these concepts share. Similarly to place (though not as paradigmatically diverse) sport tourism has been a notoriously awkward term to conceptualize. Whilst place has received much attention in this regard, sport tourism has received (with the exception of Hinch and Higham, 2009; Weed and Bull 2009) relatively little debate concerning the critical elements which contribute to a distinct conceptualization.

This chapter, therefore will revisit and evaluate current understandings of sport tourism with particular reference to the part that place takes in both its conceptualization as well as in how it is encountered and experienced. To help position this discussion better it is first necessary to map out the various approaches and debates that have contributed to the directions that sport tourism currently takes.

\section{Sport Tourism}

Although sport-related tourism has a long history (see Standeven and DeKnop, 1998, Weed and Bull, 2009) it was only in the latter part of the $20^{\text {th }}$ century that significant and sustained academic interest in the subject took shape. Arguably, the first time the two fields of sport and tourism had been brought together and discussed as a singular term (at least in English) was by Anthony (1966) in a paper for the Council of Physical Recreation in the UK. However, it was much later when the first academic studies in sport tourism began in earnest (Glyptis, 1982). The call for sport and tourism to move closer together in both political and academic terms 
became the key focus in most of the 1990s and was helped by the newly formed Journal of Sport Tourism (later to become the Journal of Sport and Tourism). In tandem with the growing debates that championed the reciprocal nature of the two fields, much work during this period attempted to first define and categorize sport tourism - which in turn encouraged more theoretically positioned studies. As is often the case when attempting to define hitherto unlabelled phenomena, definitions ranged from the deceptively simple such as that proposed by Kurtzman (1995:1): ' ...the use of sports for tourism endeavours' - to the more complex that attempt to include the temporal and spatial qualities of the field - as proposed by Hinch and Higham (2001:29): ‘...sport-based travel away from the home environment for a limited time where sport is characterised by unique rule sets, competition related to physical prowess and a playful nature'. Further definitions have been included to the mix; each of which highlighted particular features of the term. For example, some have focused on the motivational and experiential features of sport tourism (Nogowa et al, 1996; Gammon and Robinson, 1997) whilst others brought to light the social, cultural and economic implications that the conflation of sport and tourism generates (Weed and Bull, 2004). As with the separate fields of sport and tourism varying definitions abound, and although sport tourism has suffered from the same academic cacophony, the many definitions in their own way point to the simple conclusion that sport-related tourism involves travelling in order to experience sport in some way.

Categorizations too developed over this period which, similarly to the definitions outlined above, shed light on the breadth and multi-faceted nature of the field. Gibson's (1998) tripartite categorisation, delineating sport tourism into Active Sport Tourism, Event Sport Tourism and Nostalgia Sport Tourism remains a revealing and popular illustration of sport tourism types - though more recent studies have suggested that Nostalgia Sport Tourism (visits to sports museums, halls of fame and stadium tours etc.) would be better framed more broadly 
around the term heritage (Ramshaw and Gammon ,2007). In contrast Kurtzman and Zauhar's (1997) categorization highlighted what they believed to be the core products of sport tourism, namely: Tours, Resorts, Attractions, Cruises and Events. In this case the category indicates the deliverers of sport tourism, and so highlights both the potential size of the market and its economic significance. However, some commentators (Gibson, 1998; Standeven, 1998) pointed out that whilst this industry-based categorization signified the likely scope of the field it failed to capture the more synergistic qualities of sport-related tourism. An alternative classification was posited by Gammon and Robinson (1997) (augmented later by Robinson and Gammon, 2004) that aimed to highlight, through adaption of secondary reinforcement theory (Calder and Staw, 1976) the complex visitor drives that help map out the motivational interaction and transaction which takes place between primary and secondary considerations in sport tourist decision-making. In other words it was suggested that sport tourism refers to those who travel primarily to experience sport in some way, whereas tourism sport refers to those where sport is a secondary or incidental consideration to their travelling. Although this framework has been, and continues to be, applied in many sport tourism-related studies (Hudson and Hudson, 2010; Kim et al, 2008; Smith, 2010; Williams, 2008; Yusof et al, 2007 etc.) it has been criticised for assuming that either sport or tourism takes a dominant role and in so doing detracts from the synergistic qualities of the subject (Weed and Bull, 2009). Using Lefebvre's view (from Soja, 1996) of the trialectic Weed and Bull (2009) contend that sport tourism adds up to more than the sum of its parts (incidentally, an argument put forward by Gammon and Robinson, 1997; Gammon, 2003); that sport tourism’s constitutive parts should not be perceived as an additive combination but should be deconstructed and reconstructed, producing '.... a third phenomenon that is both similar and strikingly different' (Weed and Bull, 2009: 62). Confusingly Weed and Bull (2009) attribute the previous quote and its implications to the work of Lefebvre (1991) where in actuality it emanates from the work of Soja (1996:61) 
who interpreted and applied Lefebvre's ideas to his own. Notwithstanding this oversight, asking for a more holistic approach to the nature of sport tourism (originally posited by Weed, 2005) helps reveal the special unique qualities that the term implies though does not take account that, for many, the experience for sport-related tourism is sought in order to benefit from the reinforcing qualities that sport has upon tourism - and tourism has upon sport. Put simply, sport tourism is unquestionably a blend of two phenomena that will in turn create many differing yet related manifestations. In the same way that the colour green is made up from yellow and blue and will vary in hue depending on the dominance of its constituent colours so will sport tourism. However, it is important to note that the above differing approaches do not represent a discontinuity in the study of sport tourism but instead illustrate the many theoretical and philosophical directions that it can take, thereby further justifying a subject rich for study.

In reality there are probably more similarities to the positions outlined above as there are differences. Both outline the important holistic qualities of sport tourism, and both bring attention to the synergetic features of the term. They differ in that Robinson and Gammon (2004) outline the reinforcing qualities each element brings to the other whereas Weed and Bull (2009) direct attention to the unique singularity of sport tourism that transcend it from its constituent parts. They do this by conceptualising sport tourism as a unique interaction between activity, people and place which will be examined later in the chapter. The debates outlined above raise an important point concerning first, where sport tourism should be situated academically and politically, and second, what part place takes in how it is perceived, experienced and delivered. 


\section{Place and Sport Tourism}

As discussed in other chapters within this text, and so illustratively by Creswell (2004), the term place is famously awkward to pin down. It is beyond the scope of this chapter to explore all the place-related nuances that potentially impact upon sport tourism so it aims to focus upon those relatively underexplored place-implications that emanate from some of the current thinking in the field. There is little doubt that some of the most revealing and powerful descriptions of sport tourism are those that have place as a key component. For example, Standeven and De Knop (1999) believed that definitions are limiting in articulating the essence of what sport tourism actually is - that it is more revealing to identify the nature of sports tourism, which, '...is about an experience of physical activity tied to an experience of place (Standeven and De Knop, 1999:58). This deceptively simple sentence illustrates effectively the dynamic and special qualities of sport tourism that makes it, for many, an experience worth pursuing. Weed and Bull (2009:63) have developed this notion further by conceptualizing sport tourism as, '... arising from the unique interaction of activity, people and place'. Here the interactive qualities are highlighted which in turn, Weed and Bull (2009) argue, underpin their position of sport tourism being understood as free from the dominance of its constituent parts. It could be argued that this latest conceptualization lacks specificity; in that it could be applied to numerous phenomena such as shopping, socialising - or indeed any other type of tourism endeavour. It could also be questioned over the nature and significance of the uniqueness of the interactions - given that most interactions between a place, a person and a specified activity is likely to be unique in some way. Nevertheless, it represents an interesting and revealing approach that identifies the critical components that make up the sport tourism experience. 
As intimated earlier it is not the intention of this chapter to explore in detail all connections between sport tourism and place, as much has already been addressed elsewhere (Higham and Hinch, 2009). The main aim is to explore those place-based relationships and theories that have not had significant coverage in the literature, and by doing so add further argument for place to be considered as a central element of sport tourism. Previous studies have explored the place-sport tourism relationship in variety of ways, and before outlining any new approaches, it is first necessary to identify briefly some of the key studies that have already established. For example some have explored the environmental dynamics of sports places; identifying the key issues and impacts of those venues which are situated within and/or as part of the natural or built landscape (Bale 1989, Gammon, 2004; Higham and Hinch, 2009; Hudson, 2000). Other studies have examined how some sports places have the ability to trigger off powerful nostalgic emotions from those that visit them. Such experiences are more likely to occur at venues which hold some form of personal meaning to the visitor, and have been examined in the context of stadium tours (Gammon and Fear, 2007), sports heritage-themed events (Ramshaw and Hinch, 2006) sports museums and halls of fame (Fairly and Gammon,2005, Snyder, 1991). Furthermore, it has been argued that the often emotive and memorable experiences that take place at regular sporting events can themselves produce poignant reflections of the past:

Playing the sports we played when younger or watching a match in familiar surroundings can often take us back to earlier days spent with family and friends who are perhaps no longer with us. So sporting events have the ability to generate non-sporting reflections related to the way we were back then, as well as triggering bittersweet memories of the people that shared in our lives at the time (Gammon and Ramshaw, 2013). 
Since sports events and attractions are now increasingly accepted as integral parts of many tourism destinations' offerings, some studies have explored how such places are sensed and experienced by the visitor. For example Gaffney and Bale (2004) explored how sports places are felt by the spectator by predominantly drawing on the somatic senses encountered when attending a stadium event. Using a similar approach, Gammon (2011) discussed the experiences of visitors to stadia outside event conditions (mostly in the context of stadium tours) where the motives to attend differed from the live event setting in that patrons desired to access places otherwise reserved for the privileged few, such as players' locker rooms, media centres and executive boxes etc. However, what links both these studies is that a key experience sought by both sets of visitors is a desire to encounter an authentic sense of place. Those attending a sports event have the opportunity to immerse themselves in and around a people at play - and thereby achieving, through place, a closer and more intimate connection with a given community (Nauright, 1996; Jarvie, 1996; Higham and Hinch, 2009). For visitors to stadia outside event conditions the pursuit for authenticity differs in that their desires revolve around the opportunities to interact more closely with iconic sports venues, as well as with the hidden places that lie within them (Gammon, 2011, Gammon and Fear, 2007; Stevens, 2005). This layered revealing of place illustrates the myriad ways that place can be encountered. For example, at first the visitor experiences the place (town or city) in which the place (in this case the sports venue) is located, which then proceeds to entering and/or viewing the many places that reside inside. Places unsurprisingly interact with other places (Malpas, 1999), though to what extent that such interaction impacts upon the experience of the sport tourist has had scant attention in the literature and will be explored later in this chapter.

Authenticity also plays a part in the manner in which sport places are perceived as representations of home. For the ardent, highly identified fan, the team venue transcends its 
functional purpose to house sports events into a powerful and salient representation of home not just of the team but of the community of supporters that follow them (Bale 1994, 2000). Additional studies have extended this notion of home by finding that some stadia have the ability to symbolically represent not only the home of a country's sport, but also the spiritual home of a sport as well as underpinning notions of national identity (Ramshaw and Gammon, 2010). The growth in North America of retro sports stadia during the 1990 s onwards adds an additional dimension to place attachment. In this case the past is manufactured and partially recreated through the retrospective designs of ballparks. Such designs are often part of more general urban planning strategies that aim in enticing tourism - as well as offering fans new sports places which retain a familiar "feel” to those venues from the past. (Friedman, 2007). Whatever its size, design or age it is little wonder that many sports structures have become key elements in destination (re)imaging strategies, and significant features in urban regeneration initiatives. (Smith 2005).

These examples show just a snapshot of the complex and critical relationship that sport has with place. As a consequence there is no over-arching theory that frames them all but certainly those that are related to place identity and place attachment appear to be the most popular (Higham and Hinch, 2009). In addition Higham and Hinch (2009) introduce place dependence as a further dimension to the sport tourism and place research. Place dependence is a concept that draws attention to both the personal assessment of a sports place and the subjective dependence that it causes, and will help determine the nature of the relationship that sport tourists have with the sports places they visit and engage with. Undoubtedly, gaining deeper insights into the many relationships that exist between sport places and visitors is fundamental to the field. And one of the most critical aspects of these relationships must be in identifying to what extent the experience of engaging in sport as a tourist differs from that 
which is encountered at home. Studies could then move onto exploring in more detail the consequent personal impacts that such experiences engender. Place, and the manner in which it's experienced, unquestionably lies at the nub of sport tourism. Conversely, to solely focus upon the interactions that occur between place and sport may not reveal the whole picture, as the many interactions that places have with other places must also be considered. Places do not exist in a vacuum; as they can be found in and around other places, and they are often compared and contrasted with other places far removed.

\section{Unfolding Sport Tourism}

Earlier in the chapter the more conceptual issues of sport tourism were discussed, paying particular attention to Weed and Bull's (2009) contention that sport tourism can be understood as a unique interaction between activity, people and place. Considering sport tourism in these terms helps bring to light the critical elements that drive much of the research related to the area. But it is not just about the interaction between people, place and activities - sport tourism also concerns the critical interactions that occur between people and people; between activity and activity, and of course between place and place. The interaction that takes place between people in a sport tourism context has largely been addressed in quite diverse literatures. The socio-cultural impacts that can take place at spectator events has already been alluded to earlier is one such example, as are studies that have identified the strong social interactions that take place during sports participation (Caron and Hausenblaus, 1998), along with the less than positive outcomes that can occur between rival fans (Weed, 2002). The interactions between activity and activity has surprisingly had less coverage in the literature. Of course the activities that take place whilst on vacation are one of the defining elements of sport tourism and have 
been covered extensively in the literature (Kurtzman and Zauhar, 1997). Curiously, studies that have explored the complex interactions that take place between activities has been covered less which is surprising given its importance in the sport tourist decision-making process. For example the comparison between the activities engaged in at home and the activities that are offered whilst on vacation is a central consideration for many sport tourists. In fact in what way the experience(s) of sport as a tourist differs from that experienced at home should remain at the heart of all sport tourism studies. More recently Griffith (2013) has identified apprenticeship pilgrimage as a specific type of sport tourism that feeds off the desire to experience a more authentic experience of an activity through travelling to "centres" where experts in a chosen field will help deliver more legitimate tuition. This example not only highlights an interaction between activities (between home and away) but also between the relatively inauthentic place at home and the authentic place where the origins of the activity stems from (Gammon, 2004). Also, the demand to see sports legends from the past, either in competition or in an entertainment capacity suggests that a dialectic takes place between the legends’ present abilities and the achievements from their pasts (Gammon, 2014).

So what of sport tourism places? Much of sport tourism involves travelling, in order to engage and interact in some way with sport places. But sport places are not simply venues and facilities that host and/or offer sporting activities and experiences. They can represent wider, natural expanses of land and water such as those required for skiing, surfing or climbing. They can be routes from tours which are made up of many places such as starting and finishing places, and all the many other places that lie between (Berridge, 2012). Also, sport places house smaller places that hold interest and importance to the sport tourist. Stadium tours incorporate access to a number places within their venues; a practice which is essentially their primary product. In many cases events, for example the Wimbledon tennis championship, will 
offer the spectator the opportunity to encounter a number of places, from show courts to outside courts, to restaurants or the museum. Furthermore, sport museums and halls of fame add a temporal dimension to the predominantly topographic examples of place outlined above, where visitors are reminded and taken back (in a Proustian sense) to places and events from their pasts.

Sport tourism places therefore are rarely experienced in isolation; they are often related to other places which can frame and reinforce their importance and authenticity. Malpas (1999) draws attention to the manner in which places can turn inward towards other places or outward to expose others. In doing so, it is suggested that this interconnection of places promotes differing perspectives on the part(s) we play within them:

'Place always open up to disclose other places within them (within the place that is the garden or a house, a town or a countryside, there are places for different things, for different moods, for different people), While from within any particular place one can always look outwards to find oneself within some much larger expanse (as one can look from the room in which one sits to the house in which one lives.' (Malpas, 1999: 171)

There is a folding and unfolding of places that collectively reveals something deeper or different about the places we visit and inhabit - as well as revealing something about the nature of the people who occupy and visit them. Moreover, the places in which we travel from have a bearing on the choices of places we visit, as well as contributing towards the manner in which any new places are perceived and encountered (Suvantola, 2002). As way of an example, a visiting golf fan travelling to watch the golf at Augusta might be first drawn to their favourite 12th hole. They may be attracted to this hole because they know it to be deceptively difficult 
for the players to negotiate, or because it's the one hole they remember most when they watched the tournament on TV back home, or perhaps it's because of a famous sporting moment that took place there. The hole itself consists of many places: the teeing off area, Hogan Bridge, Rae’s Creek and of course the green - all of which interact with each other. Folding outwards, the hole is part of the course, which is situated in Augusta that is located in Georgia - a southeastern state of the United States. The further out, and more "unfolded" the place, the more abstract it becomes - and the more uncertain its interaction will be (Malpas, 1999). It is likely that the subjective influence and relationships that places have upon each other are dependent on the familiarity and significance which are attributed to them by the visitor. The juxtaposition between familiar and unfamiliar places may well be a critical factor in the sport tourist experience. Urry (1990) mentions that an important element of the tourist gaze is that the tourist experiences both the familiar and the different: 'There is the carrying out of familiar tasks or activities within an unusual visual environment. Swimming and other sports, shopping, eating and drinking all have particular significance if they take place against a distinctive visual backcloth' (Urry, 1990: 12). The significance of this experience within a sport tourism context requires further attention, and it is hoped that further research will shed much needed light in this area.

So sport tourism “finding its place” is not so quite straight forward as first thought. Sports places house other places within them which are, in turn, framed by other places. It may be opportune to return briefly to Weed and Bull's (2009) conceptualization of sport tourism, as the likelihood of solely focussing on the interactions that occur just between place and place ignore the fact that without people there are no places, and that for a place to be acknowledged as such, some kind of activity should take place there. Nevertheless, the complex interactions that occur between place, whether it be between the familiar and the unfamiliar, the specific 
and the general or between those at home and those away from the home environment, lies at the essence of sport tourism. Currently the nature of such interactions are unclear, but by adopting some of the approaches discussed at the beginning of this chapter, the dialogue that arises between these places will be better understood. For example does an interaction take place between sport places and tourism places, and if so will one place take preference over another? Alternatively, are there distinct sport tourism places that are perceived as such, supporting more holistic notions of the subject? Also, in what ways does the folding in and out of place impact upon the experiences of the sport tourist? Is there, as Malpas (1999) intimates, a deeper connection with place when we look outward to other places and in so doing gain a more nuanced sense of ourselves within that place? Perhaps these questions may act as starting points for future research initiatives.

From a more prosaic perspective the manner in which sport tourism is understood and defined has some important implications on where it's more likely to be positioned - both academically and politically. Although discussion outlining the holistic, synergistic qualities of sport tourism help further the cause for sport tourism to be considered as a distinct subject area it can confuse decisions as to which fields it should be best situated. Currently, sport tourism is delivered and researched in a range of departments and divisions such as those located in sport management, tourism management and geography etc. This may cause discord with Weed and Bull's (2009) anti-binary notions of sport tourism, but the reality is that it will continue to be delivered in departments that are predominantly sport or tourism-based. To what extent this effects how sport tourism is delivered and studied is unclear and again may prove to be a fruitful research project. Similarly the present schism in many government departments that frustratingly divides sport from tourism in both policy and funding seems to stem from tradition rather than an understanding of the reciprocal nature of sport tourism (Weed 2006). 


\section{Conclusion}

From both conceptual and experiential viewpoints, place is unquestionably an integral part of sport tourism. Current debates that champion the holistic nature of the subject, and those that draw attention to the reinforcing qualities that each element brings to the other will determine how place is dealt with in the future. Whilst some approaches to sport tourism have focused upon the important interactions that takes place between people, place and activities, this chapter has brought attention to the significance of the interactions that occurs in and between sport-related tourism places. Particular consideration was taken to the potential folding in and out of places and its consequent impacts to those who are engaged in sport tourism. Taking this approach highlights a central enquiry relating to how sport tourism is encountered and engaged in, and that is: do sport tourists engage in distinct sport tourism places or does such engagement only occur at sport places situated within tourism places? This seemingly unimportant difference in how places are perceived not only impacts upon future-based studies in place but also upon the broader conceptual debates posed at the beginning of the chapter.

\section{References}

Anthony (1966) Sport and Tourism. London: CCPR.

Bale, J. (1989) Sports Geography. London: E \& FN Spon.

Bale, J. (1994) Landscapes of Modern Sport. London: Leicester University Press.

Bale, J (2000). The Changing Face of Football: Stadiums and Community. Soccer \& Society, Vol. 1, No.1, pp. 91-101

Berridge, G. (2012) The Promotion of Cycling in London: the Impact of the 2007 Tour de France Depart on the Image and Provision of Cycling in the Capital. Journal of Sport and Tourism, Vol.17, No.1, pp.43-61 
Calder, B. J. and Staw, B. (1976) Self-perception of Intrinsic and Extrinsic Motivation. Journal of Personality and Social Psychology. Vol. 31, No.4, pp. 599-605

Caron, A. V. and Hausenblaus, H. L. (1998) Group Dynamics in Sport. Virginia: Fitness Information Technology.

Cresswell, T. (2004) Place: a Short Introduction. Oxford: Blackwell Publishing.

Friedman, M. (2007) The Spectacle of the Past: Leveraging History in Fenway Park and Camden Yards. In Gammon, S. and Ramshaw, G. (eds) Heritage, Sport and Tourism: Sporting Pasts - Tourist Futures. London: Routledge, pp. 103-121.

Gibson, H. (1998) Sport Tourism: A Critical Analysis of Research. Sport Management Review, Vol.1, pp. 45-76.

Glyptis, S. (1982) Sport and Tourism in Western Europe. London: British Travel Education Trust.

Gaffney, C. and Bale, J, (2004) Sensing the Stadium. In Vertinsky, P. and Bale, J. (eds) Sites of Sport: Space, Place, Experience. London: Routledge

Gammon, S. (2003). The Dissemination of Sport Tourism: Spreading the Word. The Journal of Sport Tourism, Vo. 8, No.1, pp. 5-7.

Gammon, S. (2004) Secular Pilgrimage and Sport Tourism. In Ritchie and Adair, D. (eds) Sport Tourism: Interrelationships, Impacts and Issues. Clevedon: Channel View Publications, pp. 30-45.

Gammon, S. (2011) Sporting New Attractions? The Commodification of the Sleeping Stadium. In Sharpley, R. and Stone, P. (eds) Tourist Experience: Contemporary Perspectives. London: Routledge, pp. 115-126.

Gammon, S. (2014) Heroes as Heritage: the Commoditization of Sporting Achievement. Journal of Heritage Tourism, Vo. 9, No.3, pp. 246-256.

Gammon, S and Fear, V. (2007) Stadia Tourism and the Power of Backstage. In Gammon, S. and Ramshaw, G. (eds) Heritage, Sport and Tourism: Sporting Pasts - Tourist Futures. London: Routledge, pp. 23-32.

Gammon, S. and Ramshaw, G, (2013) Nostalgia and Sport. In Garrod, B. and Fyall, A. (eds) Contemporary Cases in Sport. Oxford: Goodfellow Publishers Ltd, pp.201-219

Gammon, S. and Robinson, T. (1997) Sport and Tourism: A Conceptual Framework. Journal of Sport Tourism. Vol.4, No.3, pp. 8-24.

Griffiths, L. M. (2013) Apprenticeship Pilgrims and the Acquisition of Legitimacy. Journal of Sport and Tourism, Vol, 18, No. 1, pp. 1-15. 
Higham, J. and Hinch, T. (2009) Sport and Tourism: Globalization, Mobility and Identity. Oxford: Butterworth-Heinemann.

Hinch, T. and Higham, J. (2001) Sport Tourism: A Framework for Research. The International Journal of Tourism Research, Vol. 3, No. 1, pp45-58.

Hudson, S. (2000) Snow Business: A Study of the International Ski Industry. London: Cassell.

Hudson, S. and Hudson, L. (2010) Golf Tourism. Oxford: Goodfellow Publishers Limited. Jarvie, G. (2006) Sport, Culture and Society: An Introduction, London: Routledge.

Kim, S., Kim, J. and Richie, B.W. (2008) Segmenting Overseas Golf Tourists by the Concept of Specialization. Journal of Travel and Tourism Marketing, Vo.25, No.2, pp. 199-217.

Kurtzman, J. (1995) Sports Tourism Categories Revisited. Journal of Sport Tourism, Vol. 2, No.3, pp1-11.

Kurtzman, J. and Zauhar, J. (1997) A Wave in time - the Sports Tourism Phenomena. Journal of Sport Tourism, Vol.4, No.2, pp. 19-17.

Malpas, J. E. (1999) Place and Experience: A Philosophical Topography. Cambridge: Cambridge University Press.

Nauright, J. (1996) “A Besieged Tribe”? Nostalgia, White cultural Identity and the Role of Rugby in a Changing South Africa. International Review for the Sociology of Sport, Vol.31, No.1, pp.69-85.

Nogawa, H., Yamaguchi, Y. and Hagi, Y. (1996) An Empirical Research Study on Japanese Sport Tourism in sport-for-all events. Case Studies of a Single-Night Event and a MultipleNight Event. Journal of Travel Research, Vol. 35, No. 2, pp. 46-54

Ramshaw, G. and Gammon, S. (2007) More than nostalgia? Exploring the Heritage/Sport Tourism Nexus. In Gammon, S. and Ramshaw, G. (eds) Heritage, Sport and Tourism: Sporting Pasts - Tourist Futures. London: Routledge. pp. 9-23.

Ramshaw, G. and Gammon, S. (2010) On Home Ground? Twickenham Stadium Tours and the Construction of Sport Heritage. Journal of Heritage Tourism, Vol.5, No.2, pp. 87-102.

Ramshaw, G, and Hinch, T. (2006) Place Identity and Sport Tourism: The Case of the Heritage Classic Ice Hockey Event. Current Issues in Tourism, Vol.5, pp. 399-418.

Robinson, T. and Gammon, S. (2004) Revisiting and Applying the Sport Tourism Framework: A Question of Primary and Secondary Motives. The Journal of Sport Tourism, Vol.9, No.3, pp. 221-233.

Smith, A. (2005) Reimaging the City: The Value of Sport Initiatives. Annals of Tourism Research, Vol.32, No.1, pp229-347 
Smith, A. (2010). The Development of "Sports-City" Zones and their Potential Value as Tourism Resources for Urban Areas. European Planning Studies, Vol. 18, No. 3, pp. 385410.

Snyder, E. (1991) Sociology of Nostalgia: Halls of Fame and Museums in America. Sociology of Sport Journal, Vol. 8, No.3, pp-228-238.

Soja, E, W. (1996) Thirdspace: Journeys to Los Angeles and Other-and-Imagined Places. Oxford: Blackwell Publishers Ltd.

Standeven, J. (1998) Sport tourism: Joint Marketing - a Starting Point for Beneficial Synergies. Journal of Vacations Marketing, Vol. 4, pp.39-51.

Standeven, J. and De Knop, P. (1999) Sport Tourism. Leeds: Human Kinetics.

Stevens, T. (2005) Sport and Urban Tourism Destinations: the Evolving Sport Tourism and Leisure Functions of the Modern Stadium. In Higham, J. (ed.) Sport Tourism Destinations. Issues, Opportunities and Analysis. London: Elsevier, pp. 205-221.

Suvantola, J. (2002) Tourist's Experience of Place. Hampshire: Ashgate.

Urry, J. (1990) The Tourist Gaze. Leisure and Travel in Contemporary Societies. London: Sage

Weed, M. E. (2002) Football Hooligans as Undesirable Sports Tourists: Some Meta Analytical Speculations. In Gammon, S. and Kurtzman, J. (eds) Sport Tourism: Principles and Practice. Eastbourne: LSA Publications, pp.35-52.

Weed, M. E. (2005) Sports Tourism Theory and Method - Concepts, Issues and Epistemologies. Sport Management Quarterly, Vol. 5. No.3, pp. 229-242.

Weed, M. (2006) The Influence of Policy Makers' Perceptions on Sport-Tourism Policy Development. Tourism Review International, Vol. 10, No. 4, pp. 227-240.

Weed, M. and Bull, C. (2009) Sports Tourism: Participants, Policy and Providers. Oxford: Butterworth-Heinemann.

Williams, A. (2008) Motivational Dimensions of Equestrian Sport Tourists. International Review of Business Research Papers, Vol. 4, No.4, pp. 62-74.

Yusof, A., Shah, P. and Geok, S. (2007) Sport Events as a Tourist Attraction: A Study of the Champions Youth Cup in Malaysia. The International Journal of Sport and Society, Vol.1, No.1, pp. 69-110. 